\title{
Movements and distribution of adult Lake Sturgeon from their spawning site in the St. Clair River, Michigan
}

\author{
By J. C. Boase ${ }^{1}$, J. S. Diana ${ }^{2}$, M. V. Thomas ${ }^{3}$ and J. A. Chiotti ${ }^{1}$ \\ ${ }^{1}$ US Fish and Wildlife Service, Alpena Fish and Wildlife Conservation Office Waterford Sub-station, Waterford, MI, USA; ${ }^{2}$ School \\ of Natural Resources and Environment, University of Michigan, Ann Arbor, MI, USA; ${ }^{3}$ Michigan Department of Natural Resources \\ and Environment, Lake St. Clair Fisheries Research Station, Mount Clemens, MI, USA
}

\begin{abstract}
Summary
Lake Sturgeon Acipenser fulvescens were studied to determine spawning migrations, seasonal movement patterns and habitat use in the St. Clair River and Lake St. Clair. Ultrasonic transmitters were successfully implanted in 15 sexually mature adult fish during spawning periods in 1997-1999. Telemetry data, along with GIS software, were used to determine where Lake Sturgeon resided in Lake St. Clair following implantation. Movement information collected from tagged Lake Sturgeon from May 1997-October 2000 revealed three patterns. Following implantation, $73 \%$ of the fish (four females and seven males) moved downstream from the St. Clair River to Lake St. Clair, $13 \%$ of the fish (one female and one male) were presumed to have moved upriver to Lake Huron, and $20 \%$ of the fish (one female and two males) remained in or returned to the St. Clair River for at least 1 year. The fish that moved into Lake St. Clair were found most often in an area near the St. Clair River Delta, at depths of $4-6 \mathrm{~m}$ ( $>98 \%$ of observations). Fish that remained in the St. Clair River were commonly found ( $>84 \%$ ) at depths between 9 and $18 \mathrm{~m}$. Four females and three males returned to the spawning site in the St. Clair River in subsequent spawning seasons. Females returned at intervals of 1-3 years and males at 1-2 years. For all invertebrates tested, only Ephemeroptera density was a significant predictor of Lake Sturgeon presence / absence in Lake St. Clair.
\end{abstract}

\section{Introduction}

Lake Sturgeon Acipenser fulvescens were once widely distributed in rivers and lakes throughout North America. Within the last century, Lake Sturgeon populations have been dramatically reduced or extirpated from much of their native range by habitat degradation, over fishing, and intentional reduction (Brousseau, 1987; Harkness and Dymond, 1961). Life history traits such as longevity, large size, infrequent spawning periodicity, and late sexual maturity have made Lake Sturgeon particularly vulnerable to exploitation (Brousseau and Goodrich, 1989; Harkness and Dymond, 1961). Commercial harvest of Lake Sturgeon peaked in Lake St. Clair in 1870 at $2.4 \mathrm{~kg}$ per year and in Lake Erie in 1885 at over 11 million $\mathrm{kg}$ per year (Baldwin et al., 1979). By 1890, Lake Sturgeon populations had declined due to overfishing and habitat loss to the point where the state of Michigan initiated a Lake Sturgeon propagation program using gametes collected from wild Lake Sturgeon stocks in the Detroit River (Post, 1890; Meehan, 1909). That initiative failed and Lake Sturgeon populations continued to dwindle. Presently in the Great Lakes, Lake Sturgeon have been reduced to about $1 \%$ of their former abundance (Auer, 1999). Currently Lake Sturgeon are listed in both Michigan and Ontario as a threatened species (HayChmielewski and Whelan, 1997; Cottrill et al., 2007).

Populations of Lake Sturgeon commonly migrate long distances from their residence locations in rivers or lakes to riverine areas with rapid water currents and large benthic substrates, where they spawn (Auer, 1996). Lake Sturgeon movement patterns are complex due to differences in habitats required for spawning, foraging, and over-wintering. In many systems where Lake Sturgeon are free to move out of rivers following spawning, some fish have been documented moving up to $400 \mathrm{~km}$ to residence sites in lakes during the remainder of the year (Priegel and Wirth, 1971; Hay-Chmielewski, 1987; Auer, 1999). Populations of Lake Sturgeon have been detected in the Wolf River, Wisconsin (Lake Winnebago tributary) and the Moose River (Ontario) that remained in the river yearround even though barriers did not prevent them from moving to large adjoining lakes (Threader and Brousseau, 1986; Lyons and Kempinger, 1992). Male periodicity was every 1-2 years and female periodicity was every 3-6 years (Priegel and Wirth, 1971, 1978; Folz and Meyers, 1985). Some Lake Sturgeon show strong homing instincts for returning to spawning locations (Lyons and Kempinger, 1992; Homola et al., 2010).

Several studies have examined the movement of Lake Sturgeon between the connecting waterways of the Great Lakes including the movement between riverine and lacustrine environments. Sexually mature Lake Sturgeon tagged on the St. Lawrence River spawning grounds have been recaptured throughout the St. Lawrence River, from Lac Saint-Louis to Lac Saint-Pierre (Fortin et al., 1993). At the Algonac spawning site in the North Channel of the St. Clair River, Thomas and Haas (1998) were able to capture and mark sexually mature Lake Sturgeon during spring spawning. Subsequent recaptures suggested that adult Lake Sturgeon were moving from the spawning site on the North Channel and either to Lake St. Clair or southern Lake Huron (Thomas and Haas, 1999). Sexually mature Lake Sturgeon are also suspected to move from Lake St. Clair and areas in Lake Erie into the Detroit River for spawning (Caswell et al., 2004).

Habitat selection during summer by adult Lake Sturgeon appears to include areas with fine (silty) sediments and abundant invertebrate forage. Harkness and Dymond (1961) indicated that Lake Sturgeon generally preferred shallowwater $(<4.6 \mathrm{~m})$ with mud substrates. Adult Lake Sturgeon in northern Ontario rivers were most closely associated with 
substrates dominated by clay and sand, and dominant benthic organisms including Diptera, Hexagenia, and Trichoptera larvae (Chiasson et al., 1997). Hay-Chmielewski (1987) and Choudhury and Dick (1993) suggest Orconectes, Hexagenia, Hirudinea, and Chironomidae were preferred food items and 'muck' the preferred substrate of Lake Sturgeon in Black Lake, MI and the Hudson Bay drainage. In Lake Winnebago, where Hexagenia are rare, Tubificidae, Oligochaeta, and Chironomid larvae were the primary food items of Lake Sturgeon (Choudhury et al., 1996).

The objectives of this study were to determine Lake Sturgeon movement patterns and relate their movements to habitat availability and forage abundance in the St. Clair System. We hypothesized that (i) Lake Sturgeon migrated to the St. Clair River during spring spawning runs but resided in Lake St. Clair for the remainder of the year, and (ii) Lake Sturgeon were not randomly selecting habitats in Lake St. Clair but were inhabiting areas based on food type and abundance, in particular, they selected areas with high abundances Ephemeroptera, Diptera, and Trichoptera.

\section{Methods}

\section{Study area}

The Huron-Erie Corridor forms the connecting waterway between lakes Huron and Erie. Water leaving Lake Huron travels $64 \mathrm{~km}$ in a southerly direction, down the St. Clair River, through the largest natural delta system in the Great Lakes to Lake St. Clair. Upon leaving Lake St. Clair, water enters the Detroit River where it then travels $51 \mathrm{~km}$ south and empties into Lake Erie. The Huron-Erie Corridor serves as the border between the United States and Ontario, Canada. The main focus of this study was in the St. Clair System, which is comprised of Lake St. Clair and the St. Clair River (Fig. 1).

The upper reaches of the St. Clair River are dominated by industry on both sides of the border. In the southern reaches, urbanization is prevalent on the US side while wetlands and some agriculture dominate the Canadian side. River velocities at the surface reach $1.0 \mathrm{~m} \mathrm{~s}^{-1}$ with an average discharge rate of $5121 \mathrm{~m}^{3} \mathrm{~s}^{-1}$ (Edsall et al., 1988). After reaching the delta, flow is divided into four main channels. Navigation-related dredging in the St. Clair System began as early as 1873 and continues to the present, with a minimum depth of $8.3 \mathrm{~m}$ maintained in the shipping lane. Within the river there are natural deep holes $>24 \mathrm{~m}$, while in other areas deposition of sand has created extensive submerged bars that are $<1 \mathrm{~m}$ deep (Edsall et al., 1988).

Lake St. Clair has a mean depth of $3 \mathrm{~m}$ and a maximum natural depth of $6.4 \mathrm{~m}$. Total surface area is $1114 \mathrm{~km}^{2}$ (Bolsenga and Herdendrof, 1993). The lake receives 98\% of its inflow from the St. Clair River with the remaining 2\% coming from smaller tributaries (Clinton, Thames, and Sydenham rivers) (Edsall et al., 1988). The hydraulic retention of Lake St. Clair is between 2 and 30 days (Schwab and Clites, 1986). Two distinct water masses have been identified in Lake St. Clair based on physical and chemical differences and differences in biological productivity (Leach, 1980). The northwestern mass consists of primarily Lake Huron water and is less productive. The southeastern mass has a longer retention time in the lake (Leach, 1980). Nutrients from both urban shoreline development and intensive agriculture within the drainage result in greater biological productivity in the southeastern water mass (Leach, 1972, 1973). For the purposes

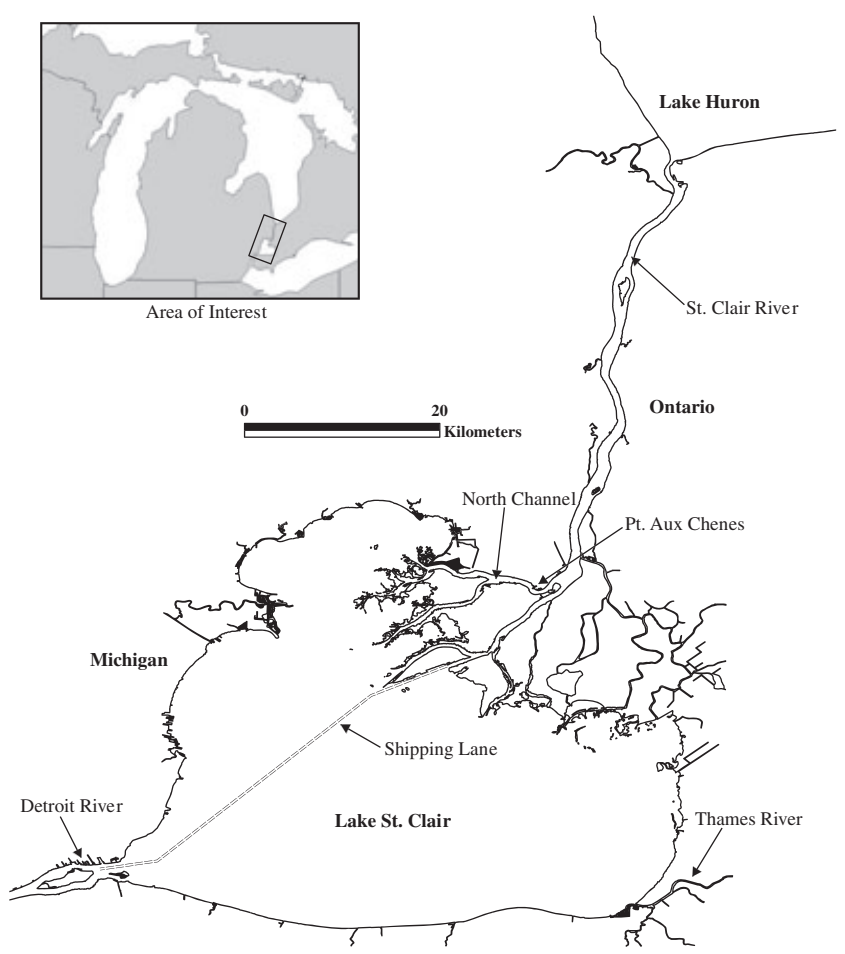

Fig. 1. Map of Lake St. Clair and the connecting waterways

of this study, telemetry observations were restricted to the St. Clair River, and Lake St. Clair.

\section{Telemetry}

We used ultrasonic telemetry of individual Lake Sturgeon to determine movement patterns. Lake Sturgeon were captured in the North Channel of the St. Clair River during spring spawning migrations in 1997, 1998, and 1999 at water temperatures between 10 and $14^{\circ} \mathrm{C}$. Water temperature data for the St. Clair River were obtained from the water treatment plant at Algonac, Michigan approximately $3 \mathrm{~km}$ above the spawning site. Lake Sturgeon were captured using setlines following methods described by Thomas and Haas (1999). All fish were captured in water depths of $10-15 \mathrm{~m}$. All Lake Sturgeon captured were greater than $140 \mathrm{~cm}$ in length total length and were determined to be sexual mature (Auer, 1999).

After initial capture, Lake Sturgeon were placed in a livewell receiving continuous flowing water from the river to maintain constant temperature and dissolved oxygen. Biological information was collected including total length $(\mathrm{mm})$, girth $(\mathrm{mm})$, weight $(\mathrm{kg})$, lamprey attachment marks, and stage of sexual maturity. Males were used if they released free flowing sperm upon first capture or by pressing on or messaging the ventral surface of the abdomen. Females that were suspected of being sexually mature either released eggs upon capture and being lifted into the boat or was verified by examination of the gonads during surgery. All females used were ovulating and had loose eggs within the body cavity. The leading ray of the left pectoral fin was removed from fish for use in age interpretation (Roussow, 1957; Rossiter et al., 1995). Ages were determined by examining the sectioned pectoral fin rays. Individual Monel tags were placed at the base of the posterior portion of the dorsal fin on each Lake Sturgeon captured.

Transmitters were implanted into the body cavity of Lake Sturgeon using procedures described in Hay-Chmielewski 
(1987). During surgery, the fish were restrained in a net stretcher and their heads covered with wet cloth to reduce trauma. In spring of 1997, the first four Lake Sturgeon captured were implanted with both radio and ultrasonic transmitters. On these four fish, two incisions were made in the abdominal cavity; one (5-8 cm long) for the insertion of both transmitters; the second ( $1 \mathrm{~cm}$ long) for the whip antenna to exit. The two remaining fish implanted in 1997, and the remainder of the fish used in this study, received only ultrasonic transmitters and required one incision $(5-8 \mathrm{~cm})$. The incision was sutured with dissolvable nylon thread and each fish was injected with an antibiotic, oxytetracyline (55 $\mu \mathrm{g} \mathrm{kg}^{-1}$ body weight). Lake Sturgeon were held in water until they were able to swim and then released. Fish were out of the water no more than 10 min during transmitter implantation.

Individually coded ultrasonic transmitters (model CHP-87L) were manufactured by Sonotronics Inc. (Tucson, AZ). Transmitters operated at $75 \mathrm{kHz}$, were $18 \mathrm{~mm}$ in diameter and $90 \mathrm{~mm}$ long, and weighed $15 \mathrm{~g}$ in water and $38 \mathrm{~g}$ out of water. Radio transmitters in the $49-50 \mathrm{MHz}$ range were manufactured by Advanced Telemetry Systems (ATS Isanti, $\mathrm{MN}$ ); the model used was $2 \mathrm{C} 6 \mathrm{~V}$, each with a trailing antenna. Transmitters were $33 \mathrm{~mm}$ in diameter and $115 \mathrm{~mm}$ long, and weighed $140 \mathrm{~g}$ out of water. The combined weight of the transmitters amounted to $<2 \%$ of total body mass of the fish.

In 1997, attempts were made by boat and by helicopter to follow fish implanted with radio transmitters, but they were unsuccessful. Lake Sturgeon were thereafter tracked by boat or from land, using an ultrasonic receiver and a hand-held directional hydrophone. A systematic grid of listening stations was used, and distance traveled between listening stations was dictated by weather conditions and sound attenuation caused by boat traffic or water surface disturbance. Typical detection ranges were $>1.5 \mathrm{~km}$. Listening locations were separated by about $0.8 \mathrm{~min}$ latitude or $1.0 \mathrm{~min}$ longitude. Using this method, large portions of the lake could be systematically searched with low likelihood that fish in the area were not detected. It was possible to search all areas of the lake and most sections of the river in approximately $40-45 \mathrm{~h}$ of effort, when conditions were favorable. When fish were first located, they were advanced upon until the transmitter signal exhibited equal strength in all directions. The amount of error locating fish due to hydrophone limitations was assumed to be $\pm 10 \mathrm{~m}$, based on distances we could move before the telemetry signal became directional again.

In the St. Clair River, distance between listening stations was often determined by direction changes in the river and were sometimes $<1.5 \mathrm{~km}$. Fish locations and listening locations were georeferenced using a Global Positioning System. When a fish was located, water depth and temperature were also recorded. Fish searches were conducted during daylight hours at least weekly from May through August, monthly from September through November, and rarely in winter due to poor ice conditions.

To facilitate analysis and better manage tracking and Lake Sturgeon information, a 1 by 1 min latitude/longitude grid of Lake St. Clair was constructed. The grid and all other geographic analysis were done using ArcView Geographic Information Software (GIS; ESRI, Inc., Redlands, CA). Lake Sturgeon locations and listening stations were plotted from May 1997 through October 2000 on the grid map. Because fish movements often encompassed both riverine and lacustrine locations, the linear extent of movement (range) was estimated, rather than area of movement, which could underestimate the importance of movements in the river. Range of each individual fish residing in Lake St. Clair and the St. Clair River was determined by taking the linear distance between the two points located the furthest distance apart. Calculations for range did not include the migration of individuals to the North Channel in the spring or migration from the river shortly after the spawning period, but did include other riverine movements.

Tracking data from May 1997 through December 1999 were used to determine areas of Lake St. Clair that were most often frequented by adult Lake Sturgeon based on relocation observations. To accomplish this, all listening stations were plotted and then each point was buffered with a radius of $1.5 \mathrm{~km}$ to represent the total area of detection. Listening episodes counted for each grid cell included episodes completely covering a cell and those from adjacent grid cells whose buffered area encompassed at least half of the cell. These listening events were then used to produce a GIS theme depicting frequency of occurrence of adult Lake Sturgeon in different parts of Lake St. Clair. Overall frequency of occurrence for each grid cell was derived by dividing the total number of Lake Sturgeon found in a grid cell by the number of searches conducted in that grid in a given year. Complete lake sampling could not be accomplished in 1 day, and weather occasionally prevented completion of the sampling for all sites in subsequent days. A sampling year was defined from March of 1 year until March of the next year. Because each spring more fish with transmitters were added to the population, a correction was required to compare frequency of occurrence across years. The equation used was $F=\left(T_{\mathrm{f}} / T_{\mathrm{s}}\right)^{*} 1 / \mathrm{n}$; where $F$ is the frequency of occurrence of Lake Sturgeon in the cell, $T_{\mathrm{f}}$ is the total number of fish found in the cell, $T_{\mathrm{s}}$ is the total number of searches in the cell, and $n$ is the number of fish tracked in that year.

Frequency of occurrence data for Lake Sturgeon collected from May 1997 through December 1999 were used to separate Lake St. Clair into four strata of Lake Sturgeon use: no use $(F=0)$, low use $(F=0.0001-0.003)$, moderate use $(F=0.0031-0.009)$, and high use $(F=0.0091-0.04)$. Sites where sediment composition and abundance of benthic invertebrates was determined was based on strata and contour depth. Habitat sampling stations were randomly chosen within each depth contour and within cells of high, moderate, low and no use. Three sampling stations were chosen for each stratum for a total of 48 stations. Because of irregular Lake Sturgeon locations, not all frequency of occurrence strata were represented for each depth contour.

\section{Invertebrate sampling}

On 25-27 May 2000, three samples of benthic invertebrates and three samples of sediment were collected at each sampling station. Samples were collected using Ponar with a $232 \mathrm{~cm}^{2}$ jaw opening, rinsed in a \#30 $(0.65 \mathrm{~mm})$ benthos bucket and preserved in a 70\% ethanol/ rose bengal solution. Preserved benthic samples were hand sorted and enumerated within 6 months using a microscope under $10 \times-40 \times$ magnification to determine invertebrate densities. Organisms were identified to order, family, or genus species. Values were reported as number / sample for all organisms except for Veneroida which was expressed in (wet weight) grams / sample due to variations in size. 
A subsample of sediment was collected from each Ponar sample to determine percent by weight of organic carbon, sand, silt, and clay at each sampling location. Samples were placed in a drying oven at $104^{\circ} \mathrm{C}$ for $24 \mathrm{~h}$, then in a desiccation chamber until cool. To determine percent organic carbon, approximately $1 \mathrm{~g}$ of material was combusted at $550^{\circ} \mathrm{C}$ for $3 \mathrm{~h}$, and percent organic carbon determined by standard methods (Rand et al., 1975). The remainder of the sample was used in a hydrometric procedure to determine substrate particle size (Gee and Bauder, 1986). Percent sand and clay were determined by this method, while percent silt was estimated as the fraction remaining.

\section{Statistical analyses}

Logistic regression was used to determine relationships between invertebrate densities and the presence/absence of lake sturgeon. Presence/absence was determined by whether or not a lake sturgeon was relocated in a grid. Wald tests were used to determine if invertebrate densities were significant predictors of lake sturgeon presence / absence. If a significant relationship was found, the area under the receiver operating characteristic curve (AUC) was calculated to assess model predictability. A measure of the predictive ability of AUC values were as follows: poor $(0.5-0.7)$, reasonable $(0.7-0.9)$, and very good (0.9-1.0) (Swets, 1988). Nagelkerke $R^{2}$ values were also reported to assess model fit. Since substrate data could not be normalized using data transformations, Spearman's rank correlations were used to test for relationships between percent substrate type (organic carbon, sand, silt, clay) and invertebrate densities. Correlation coefficients $(\rho)$ were calculated. Results for all statistical tests were considered significant at $\mathrm{P} \leq 0.05$.

\section{Results}

Transmitters implanted in the 16 Lake Sturgeon had an expected battery life of 18 months, but they lasted 42 months with a noticeable decrease in reception on or about month 36 . In total, fish were searched for on 182 different days starting on 30 May 1997 and ending on 20 October 2000. A total of 2758 listening locations were used, with 349 different fish locations being identified in Lake St. Clair and the St. Clair River (Table 1).
Lake Sturgeon were found most often at depths of 4-6 $\mathrm{m}$ in Lake St. Clair. More than $50 \%$ of the fish observations were at $5 \mathrm{~m}$ and 11 of the 16 fish used in this study were observed at this depth. Only one fish was found in areas of the lake with depths $<3 \mathrm{~m}$, and no fish were found at depths $>7 \mathrm{~m}$. In the St. Clair River, fish were found at depths ranging from 4 to $24 \mathrm{~m}$. Lake Sturgeon were not found in areas of the river where depths were $<3 \mathrm{~m}$ or in the shipping lane.

Spawning migrations to the North Channel and patterns of out-migration were dependent on water temperature. Implanted Lake Sturgeon were most abundant at the spawning site when temperatures were between 10 and $14^{\circ} \mathrm{C}$. The time period from first appearance at the spawning site until return to the lake averaged 43 days. Most Lake Sturgeon moved away from the spawning area as water temperatures increased above $14^{\circ} \mathrm{C}$, and moved out of the river when water temperatures reached $16^{\circ} \mathrm{C}$. Using $10^{\circ} \mathrm{C}$ as the beginning of spawning and $16^{\circ} \mathrm{C}$ as the end, in 1997 the estimated spawning period occurred from 23 May to 1 June, in 1998 from 1 May to 18 May, in 1999 from 4 May to 6 June, and in 2000 from 6 May to 7 June.

Post spawning, Lake Sturgeon followed three general patterns of movement, $73 \%$ moved downriver into Lake St. Clair, 13\% moved upriver into Lake Huron, and 20\% resided in or returned to the river for more than 1 year. We had location information from one implanted fish that we deleted from our study because we suspected the fish had either died or had passed the tag shortly after implantation. Post spawning movement patterns, we detected no discernable differences between male and female Lake Sturgeon.

In Lake St. Clair most fish occupied an area near the St. Clair River Delta, which resulted in the contiguous low, medium, and high frequency of occurrence grids (Fig. 2). The St. Clair River delta is a large depositional area extending 2$4 \mathrm{~km}$ into the lake with depths $<1 \mathrm{~m}$. Beyond this area, water velocities decrease and the bottom gradient slopes to $3 \mathrm{~m}$ deep within a few hundred meters. Lake Sturgeon were found starting at the $3 \mathrm{~m}$ depth contour through an area extending into deeper water, with the shipping channel as the southern boundary. Fish that remained off the delta had ranges between $18.1 \mathrm{~km}$ for the largest and $4.8 \mathrm{~km}$ for the smallest with a mean range of $11.5 \pm 1.6 \mathrm{~km}(\mathrm{SD})$. The Lake Sturgeon that traveled away from the delta region and across the shipping lane could be found in the southern basin during multiple

Table 1

Length, weight, estimated age and tracking statistics for lake sturgeon used in this study

\begin{tabular}{|c|c|c|c|c|c|c|c|}
\hline $\begin{array}{l}\text { Fish } \\
\text { number }\end{array}$ & Sex & $\begin{array}{l}\text { Total length } \\
(\mathrm{mm})\end{array}$ & $\begin{array}{l}\text { Total weight } \\
(\mathrm{kg})\end{array}$ & $\begin{array}{l}\text { Estimated } \\
\text { age (years) }\end{array}$ & Date implanted & Date last located & $\begin{array}{l}\text { Number of } \\
\text { sightings }\end{array}$ \\
\hline 1 & $\mathrm{~F}$ & 1524 & 33.0 & NA & May 30, 1997 & May 30, 1997 & 2 \\
\hline 2 & $\mathrm{~F}$ & 1524 & 31.5 & NA & May 30, 1997 & August 23, 2000 & 21 \\
\hline 3 & $\mathrm{~F}$ & 1575 & 31.0 & 36 & June 2, 1997 & December 13, 1999 & 9 \\
\hline 4 & M & 1762 & 45.5 & 42 & June 2, 1997 & July 15,1999 & 37 \\
\hline 5 & $\mathrm{~F}$ & 1397 & 17.1 & 26 & June 5, 1997 & June 6,2000 & 42 \\
\hline 6 & M & 1461 & 19.0 & 28 & June 5, 1997 & August 28, 2000 & 9 \\
\hline 7 & M & 1455 & 20.5 & 29 & May 19, 1998 & June 8,2000 & 29 \\
\hline 8 & M & 1544 & 30.4 & 31 & May 19, 1998 & October 20,2000 & 27 \\
\hline 9 & M & 1448 & 21.2 & 25 & May 19, 1998 & August 28, 2000 & 39 \\
\hline 10 & M & 1422 & 18.5 & 17 & May 19, 1998 & October 20,2000 & 33 \\
\hline 11 & M & 1537 & 21.3 & 25 & May 26, 1999 & August 28,2000 & 10 \\
\hline 12 & M & 1412 & 18.4 & 26 & May 26, 1999 & May 29, 1999 & 2 \\
\hline 13 & $\mathrm{M}$ & 1852 & 25.8 & 38 & May 26, 1999 & June 20,2000 & 15 \\
\hline 14 & $\mathrm{~F}$ & 1435 & 18.8 & 28 & May 26, 1999 & August 232000 & 27 \\
\hline 15 & $\mathrm{~F}$ & 1816 & 49.5 & 62 & June 3, 1999 & June 11,1999 & 3 \\
\hline 16 & $\mathrm{~F}$ & 1537 & 31.0 & 44 & June 3, 1999 & September 27, 2000 & 18 \\
\hline
\end{tabular}




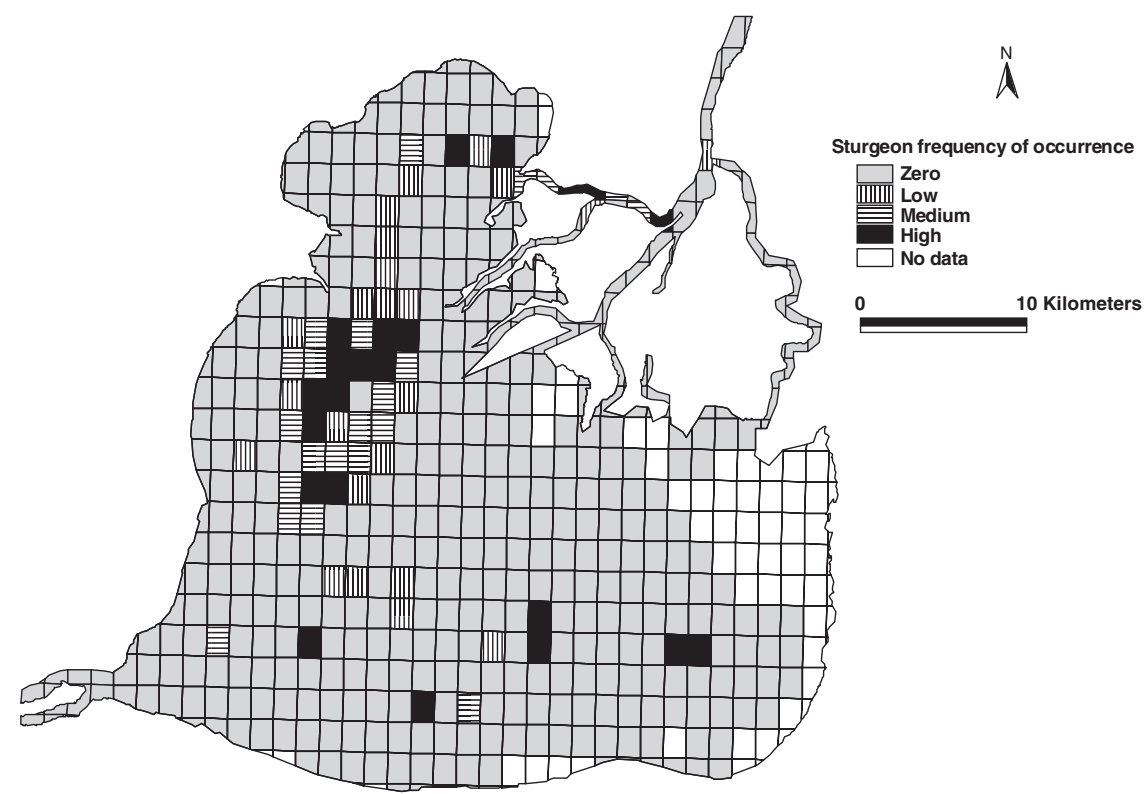

Fig. 2. Lake Sturgeon frequency of occurrence for Lake St. Clair and the lower St. Clair River years. These fish did not localize in any specific area but were in waters $3 \mathrm{~m}$ or deeper and traveled over a much larger area of the lake (Fig. 2). Range for this group was $26.3 \pm 1.2 \mathrm{~km}$ (SD); with the largest range of $27.9 \mathrm{~km}$, and the smallest $24.0 \mathrm{~km}$.

In addition to the patterns of fish residing in Lake St. Clair, Lake Sturgeon remained in the river or returned to the river during non-spawning periods. Although Lake Sturgeon were tracked moving through other sections of the St. Clair River, the North Channel was the only section where fish resided. Fish that resided in the river were there for periods ranging from 12 to 19 months. Fish tended to localize off Pt. Aux Chenes in the North Channel. This segment of the river is characterized by a sharp bend in the river with depths $>20 \mathrm{~m}$. The sharp bend at Pt. Aux Chenes, followed by a deep hole, provides an eddy where the river bottom is dominated by soft substrates and organic debris. River-resident Lake Sturgeon had ranges of $10.1-14.0 \mathrm{~km}$ with a mean of $12.0 \pm 1.1 \mathrm{~km}(\mathrm{SD})$.

Migrations of fish from the lake to riverine spawning sites, and return migrations to the lake were difficult to characterize because these movements took place between one sighting and the next and the distances traveled could be up to $30 \mathrm{~km}$. Most commonly, fish were found in the lake on 1 day and in the river at the next sighting, sometimes several days later. Of the 15 fish tracked during this study $73 \%$ returned to the North Channel spawning locations in subsequent springs, including five females and six males. Females returned at intervals of $1-$ 3 years and males returned at intervals of 1-2 years.

Macroinvertebrates were collected in August 2000 from 134 Ponar samples collected at 48 habitat sampling locations. We had five dominant orders that were collected, Veneroida, Diptera, Trichoptera, Amphipoda, and Ephemeroptera (Table 2). Veneroida consisted of $99.9 \%$ Dreissena polymorpha, Diptera consisted of over 95\% Chironomidae, Ephemeroptera consisted of $99 \%$ Hexagenia limbata, and Amphipoda consisted of $98 \%$ Gammarus fasciatus. Isopoda and Odonata had excess zero density values and organisms from the phyla Nematoda and Annelida were fragmented during processing and consequently not used in the analysis.

Ephemeroptera density was a significant predictor of Lake Sturgeon presence/absence in Lake St. Clair $(\mathrm{P}=0.03$;
Coefficient $=0.005$ ). Therefore, the odds of relocating a Lake Sturgeon increased as Ephemeroptera density increased, however model diagnostics indicate that Ephemeroptera density was not a very good fit to the presence/absence data (AUC $=0.53 ; R^{2}=0.06$ ). Densities of Veneroida, Trichoptera, Diptera and Amphipoda did not significantly predict Lake Sturgeon presence/absence in grid locations. Correlations between invertebrate densities and substrate type revealed several significant relationships. Ephemeroptera density was positively correlated with percent organic carbon $(\mathrm{P}=0.001 ; \rho=0.27)$ and percent silt $(\mathrm{P}<0.001 ; \rho=0.43)$

Table 2

Macroinvertebrates identified from Ponar dredge samples. Invertebrates were identified to order, family or genus

\begin{tabular}{|c|c|c|c|}
\hline Phylum / Order & Family & $\begin{array}{l}\text { Genus / } \\
\text { Species }\end{array}$ & $\begin{array}{l}\text { Number } \\
\text { Weight }\end{array}$ \\
\hline \multicolumn{4}{|l|}{ Nematoda $^{a}$} \\
\hline \multicolumn{4}{|l|}{ Annelida } \\
\hline \multicolumn{4}{|l|}{ Oligochaeta $^{a}$} \\
\hline Hirudinea $^{\mathrm{a}}$ & & & 16 \\
\hline \multicolumn{4}{|l|}{ Arthropoda } \\
\hline Amphipoda ${ }^{\mathrm{b}}$ & Gammaridae & $\begin{array}{c}\text { Gammarus } \\
\text { fasciatus }\end{array}$ & 118 \\
\hline Isopoda & & & 2 \\
\hline \multicolumn{4}{|l|}{ Insecta } \\
\hline \multirow[t]{4}{*}{ Ephemeroptera ${ }^{\mathrm{b}}$} & Ephemeridae & $\begin{array}{l}\text { Hexagenia } \\
\text { limbata }\end{array}$ & 243 \\
\hline & Potamanthidae & & 1 \\
\hline & Caenidae & & 2 \\
\hline & Coenagrionidae & Enallagma sp. & 1 \\
\hline \multicolumn{4}{|l|}{ Odonata } \\
\hline Trichoptera $^{\mathrm{b}}$ & & & 28 \\
\hline Diptera $^{\mathrm{b}}$ & Chironomidae & & 698 \\
\hline Diptera & Other & & 32 \\
\hline \multicolumn{4}{|l|}{ Mollusca } \\
\hline Gastropoda & & & $0.14^{\mathrm{c}}$ \\
\hline \multirow{2}{*}{ Veneroida $^{b}$} & Sphaeriidae & & $0.30^{\mathrm{c}}$ \\
\hline & Dreissenidae & $\begin{array}{l}\text { Dreissena } \\
\text { polymorpha }\end{array}$ & $484^{\mathrm{c}}$ \\
\hline
\end{tabular}

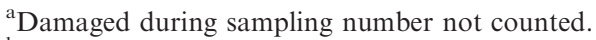

${ }^{\mathrm{b}}$ Categories used for analysis.

${ }^{\mathrm{c}}$ Wet weight in grams. 
and negatively correlated with percent sand $(\mathrm{P}<0.001$; $\rho=-0.42$ ). Amphipoda density was positively correlated with percent sand $(\mathrm{P}=0.02 ; \rho=0.19)$ and negatively correlated with percent organic carbon $(\mathrm{P}=0.002 ; \rho=-0.26)$ and percent silt $(\mathrm{P}=0.01 ; \rho=-0.21)$. No significant correlations existed between Veneroida, Trichoptera, and Diptera densities and any substrate type.

\section{Discussion}

The first objective of this study was to establish movement patterns of adult Lake Sturgeon spawning in the North Channel of the St. Clair River. We postulated that Lake Sturgeon collected during spawning were coming from and would return to Lake St. Clair. However, there were three patterns of movement: migrations into Lake St. Clair following spawning, migration into Lake Huron, or continued residence in the river. Of the 15 fish used in this study, $73 \%$ were out-migrating from the North Channel spawning site to Lake St. Clair and then migrated back in subsequent years.

We expected forage to be abundant throughout the lake, and therefore postulated that Lake Sturgeon would not need to travel great distances in search of food. This expectation was reflected in the data we collected, as ranges of individual fish varied from only 5-30 km. Fish from the Sturgeon River (a Lake Superior tributary) traveled between 70 and $280 \mathrm{~km}$ from the tagging site, most likely due to poorer benthic productivity in Lake Superior (Auer, 1999). Priegel and Wirth (1971) found that Lake Sturgeon in Lake Winnebago traveled throughout the lake but each had a smaller home range than we found for Lake St. Clair. Because we suspect that two of the Lake Sturgeon from this study moved $45 \mathrm{~km}$ into Lake Huron, the overall extent of movement in this study could also have been greater than we measured in Lake St. Clair.

Relative to other studies, Lake Sturgeon in Lake St. Clair had relatively small ranges, however, fish residing in Lake St. Clair exhibited some interesting movement patterns. Of the 11 fish that out-migrated back to Lake St. Clair, only three fish crossed over the shipping lane and into the southeastern side of the lake. We did not test for differences in the benthic community between the northwestern water mass that is dominated by the less productive Lake Huron water and more productive southeastern water mass that is dominated by the Thames River (Leach, 1972, 1973, 1980). Based on habitats used in the Detroit River (Caswell et al., 2004) and our findings in the St. Clair River, Lake Sturgeon tend to avoid the major navigation lanes. We speculate that the shipping channel that bisects the lake is altering fish behavior and limiting their movement into the southeastern basin of Lake St. Clair.

We were able to follow most Lake Sturgeon over three spawning periods and estimate the timing of return migrations to spawn. From the 11 fish that resided in Lake St. Clair following implantation, six returned to the North Channel spawning site in subsequent years. Three fish, defined as river residents, also returned to the spawning area from locations in a different part of the river. Homing behavior has been demonstrated in other Lake Sturgeon studies (Folz and Meyers, 1985; Lyons and Kempinger, 1992; Auer, 1999), although $10-20 \%$ of Lake Sturgeon tracked in the Lake Winnebago system did not return to their home river location to spawn (Lyons and Kempinger, 1992).

Males in this study returned to the spawning site 1-2 years after their initial transmitter implantation, and females from 1 to 3 years. It has been suggested that spawning by either sex of
Lake Sturgeon does not occur annually (Harkness and Dymond, 1961; Bruch and Binkowski, 2002). Other research has documented males spawning at biennial intervals (Mosindy and Rusak, 1991) and in some populations males may spawn annually (Lyons and Kempinger, 1992). Males from the Sturgeon River population near Lake Superior returned to the riverine spawning site every 2-6 years while females returned every 3-7 years (Auer, 1999). Three studies of the Lake Winnebago system found females returning every 3-6 years (Priegel and Wirth, 1971; Folz and Meyers, 1985; Lyons and Kempinger, 1992). We could not capture individuals we had implanted with transmitters to determine their maturity level when they returned to the spawning site. Because of this, we based spawning periodicity on the assumption that Lake Sturgeon were spawning, if they migrated to the spawning site in spring. This assumption was also made in other telemetry studies (Caswell et al., 2004). However, it is likely that some of these fish returned to the spawning site but did not spawn, given the short interval between their movements into the North Channel.

Some Lake Sturgeon remained in the North Channel for an extended period of time outside the spawning season. Our findings are consistent with studies conducted on the Rainey River, Ontario (Rusak and Mosindy, 1997). However, in most studies where Lake Sturgeon had access to lacustrine habitats, post-spawning fish moved downstream out of the river shortly after the spawning period ended (Baker, 1980; Hay-Chmielewski, 1987; Auer, 1999). Studies on the Lake Winnebago system also recorded a downstream migration following spawning (Priegel and Wirth, 1971). However, a more recent tagging study on the Winnebago system found substantial numbers of adult Lake Sturgeon in fall, in the Wolf River, the same river where they spawned (Lyons and Kempinger, 1992). Auer (1999) suggested that movement out of spawning rivers may be related to river conditions, since outmigration would prevent stranding, exposure to sunlight, and exposure to predators in shallow rivers. Since the St. Clair River is generally quite deep, outmigration for safety may be unnecessary. Adults feeding in the same river tended to be separated from recently deposited eggs and newly hatched fish to avoid cannibalism (Auer, 1999), and in our study, fish that remained in the North Channel after spawning moved upriver and downriver from the known spawning site.

Our second postulate of this study was that Lake Sturgeon selected habitat in Lake St. Clair based on forage abundance and type. The areas used and not used by Lake Sturgeon based on relocation observations were significantly related to Ephemeroptera density (99\% Hexagenia limbata). However, mean densities of other dominant benthic food taxa (Dreissena polymorpha, Chironomidae, and Gammarus fasciatus) found in this study were not related to Lake Sturgeon occurrence.

Lake Sturgeon residing in Lake St. Clair selected water depths between 4 and $6 \mathrm{~m}$ (over $98 \%$ of the time). At those depths substrates were composed primarily of silt. Considering that much of the lake is within preferred depth ranges, and silt substrates dominate the deeper portions of the lake, we expected to find Lake Sturgeon distributed more widely in deeper areas following spawning. However, most Lake Sturgeon that migrated to the lake were located in only a small portion of the lake near the delta at depths between 4 and $6 \mathrm{~m}$, and many other locations in that depth range showed no use by fish implanted with transmitters.

The concentration of Lake Sturgeon locations in transition areas of water currents, such as the delta region of Lake St. 
Clair, was consistent with other studies. Knights et al. (2002) determined that Lake Sturgeon on the upper Mississippi River were consistently found in transition areas between high and low water velocities. In the St. Croix River, Lake Sturgeon were mainly found at a location where the river widened into a riverine lake (Engel, 1990). In both of these studies, the authors speculated that those depositional areas resulted in higher silt concentrations and, as a result, were probably important Lake Sturgeon feeding sites.

Although invertebrate densities were highly variable in Lake St. Clair, abundance of Hexagenia was linked to substrate type. Hexagenia typically live in U-shaped tubes in soft, silty substrate, and require sediments soft enough for burrowing and firm enough to maintain integrity of the tube (Edmunds et al., 1976). Two benthic studies completed in the 1980s had conflicting results with regard to Hexagenia densities in Lake St. Clair. In 1982, Hiltunen and Manny (1982) found that Hexagenia densities were 1.5 times higher in Anchor Bay (mean depth $<3.0 \mathrm{~m}$ ) than in the deeper open lake. Thornley (1985) determined that the abundance of Hexagenia was linked to substrate size with the highest densities being found in the deeper areas of Lake St. Clair, areas dominated by silt substrates. In our study, Hexagenia densities increased with increasing amounts of silt. We conclude that the combination of appropriate depth and invertebrate density are important to Lake Sturgeon, instead of invertebrate density alone.

The extent of Lake Sturgeon movements are complex, and information on movements is important to fishery managers for conservation purposes. Because Lake Sturgeon tended to congregate in limited areas of the lake, our telemetry information enabled Thomas and Haas (2000) to target our locations to improve their capture and tagging of Lake Sturgeon, and estimate that the population for the St. Clair System in 2000 was 45506 (95\% CI 24 230-86 190). Fish locations in the St. Clair River in spring could have been used to identify new spawning sites, and also areas that may be important for staging or resting. However, setline collections in the St. Clair River have not delimited any other spawning sites, although scuba diving has found another spawning site near Port Huron (Manny and Kennedy, 2002), which was not utilized by any of the Lake Sturgeon tracked in this study.

Throughout the Great Lakes region, plans are being proposed and implemented to rehabilitate Lake Sturgeon in their native ranges (Manny and Morh, 2010). Knowledge of habitat requirements, habitat utilization during various life stages, and identification and protection of critical habitat is key to rehabilitating this species (Hay-Chmielewski and Whelan, 1997; Holey et al., 2000). In the downstream section of the St. Clair River, appropriate substrate (large rocks in rapid currents) appears to be limiting to Lake Sturgeon spawning, and fish from Lake St. Clair congregate in a small area of man-made substrate for spawning (Nichols et al., 2003; Caswell et al., 2004). Information from this study on spawning movements, river residence, and habitat selection in lacustrine areas provides basic knowledge of important movement patterns and Lake Sturgeon habitat in the Great Lakes to best protect those habitats.

\section{Acknowledgements}

This study was funded by the National Oceanic and Atmospheric Administration (National Marine Fisheries Service, Grant Number NA96FA0254), Michigan Department of Natural Resources, and Detroit Edison. We appreciate the assistance of the University of Michigan and the Michigan Department of Natural Resources, Fisheries Division. This work could not have been completed without the dedicated work and assistance of R. Beasley, C. Boase, K. Boase, M. Diana, B. Gillette, J. Hodge, K. Koster, P. Rentschler, and S. Wells. B. Haas, L. Hay-Chmielewski, and E. Rutherford provided valuable guidance, knowledge and time that were key to the success of this study. E. Roseman, B. Manny, P. Thompson, and A. Horne provided valuable comments and editorial assistance with this manuscript.

\section{References}

Auer, N. A., 1996: Importance of habitat and migration to sturgeons with emphasis on lake sturgeon. Can. J. Fish. Aquat. Sci. 53(Suppl. 1), 152-160.

Auer, N. A., 1999: Population characteristics and movements of lake sturgeon in the Sturgeon River and Lake Superior. J. Great Lakes Res. 25, 282-293.

Baker, J. P., 1980: The distribution, ecology, and management of the lake sturgeon (Acipenser fulvescens Rafinesque) in Michigan. Michigan Department of Natural Resources, Fisheries Research Report No. 1883.

Baldwin, N. S.; Saalfeld, R. W.; Ross, M. A.; Buettner, H. J., 1979: Commercial fish production in the Great Lakes 1867-1977. Great Lakes Fishery Commission, Technical Report No. 3, Ann Arbor, MI, 187 pp.

Bolsenga, S. J.; Herdendrof, C. E., (Eds), 1993: Lake Erie and Lake St. Clair handbook. Wayne State University Press, Detroit, MI.

Brousseau, C. S., 1987: The lake sturgeon (Acipenser fulvescens) in Ontario. In: Proceedings of a workshop on the lake sturgeon (Acipenser fulvescens). C. H. Oliver (Ed). Ontario Fishery Technical Report No. 23, pp. 2-9.

Brousseau, C. S.; Goodrich, G. A., 1989: Fisheries and yields in the Moose River Basin, Ontario. In: Proceedings of the International Large River Symposium. D. P. Dodge (ed.). Canadian Special Publication, Fisheries and Aquatic Science 106, pp. 145-158.

Bruch, R. M.; Binkowski, F. P., 2002: Spawning behavior of lake sturgeon (Acipenser fulvescens). J. Appl. Ichthyol. 18, 570-579.

Caswell, N. M.; Peterson, D. L.; Manny, B. A.; Kennedy, G. W., 2004: Spawning by lake sturgeon (Acipenser fulvescens) in the Detroit River. J. Appl. Ichthyol. 20, 1-6.

Chiasson, W. B.; Nokes, D. L. G.; Beamish, F. W. H., 1997: Habitat, benthic prey, and distribution of juvenile lake sturgeon (Acipenser fulvescens) in northern Ontario rivers. Can. J. Fish. Aquat. Sci. 54, 2866-2871.

Choudhury, A.; Dick, T. A., 1993: Parasites of lake sturgeon, Acipenser fulvescens Rafinesque, 1817 (Chondrostei: Acipenseridae) from Central Canada. J. Fish Bio. 42, 571-584.

Choudhury, A.; Bruch, R.; Dick, T. A., 1996: Helminths and food habits of lake sturgeon Acipenser fulvescens from the Lake Winnebago system, Wisconsin. Am. Mid. Nat. 135, 274-282.

Cottrill, R. A.; Good, J. M.; Gile, S. R., 2007: Lake Huron Commercial Fishing Summary for 2006. Ontario Ministry of Natural Resources Upper Great Lakes Management Unit, Lake Huron Report TR-LHA-2007-1.

Edmunds, G. F.; Jensen, S. L.; Burrier, L., 1976: The mayflies of North and Central America. University of Minnesota Press, Minneapolis, MN.

Edsall, T. A.; Manny, B. A.; Raphael, C. N., 1988: The St. Clair River and Lake St. Clair, Michigan: an ecological profile. US Fish and Wildlife Service, Biological Report 85(7.3), Slidell, LA.

Engel, M. P., 1990: Population parameters of lake sturgeon in the St. Croix River with special reference to movements. Wisconsin Department of Natural Resource, Sum. Rep., Baldwin, WI.

Folz, D. J.; Meyers, L. S., 1985: Management of the lake sturgeon, Acipenser fulvescens, population in the Lake Winnebago system, Wisconsin. In: North American Sturgeons. F. P. Binkowski ; S. I. Doroshov (eds.). Junk Publishers, Netherlands, pp. 163.

Fortin, R.; Mongeau, J.; Desjardins, G.; Dumont, P., 1993: Lawrence and Ottawa River system, Quebec. Can. J. Zool. 71, 638-650.

Gee, G. W.; Bauder, J. W., 1986: Particle-size analysis. In: Methods of soil analysis 2nd edition, Number 9, Part 1. A. Klute (ed.). American Society of Soil Agronomy, Inc. and Soil Science Society of America, Madison, WI, pp. 283-311. 
Harkness, W. J. K.; Dymond, J. R., 1961: The lake sturgeon: the history of its fishery and problems of conservation. Ontario Department of Lands and Forests, Fish and Wildlife Branch, Toronto, ON, Canada.

Hay-Chmielewski, E. M., 1987: Habitat preference and movement patterns of the lake sturgeon(Acipenser fulvescens) in Black Lake, Michigan. Michigan Department of Natural Resource, Fisheries Research Report 1949, Ann Arbor, MI.

Hay-Chmielewski, E. M. ; Whelan, G. E., 1997: Lake sturgeon rehabilitation strategy. Michigan Department of Natural Resources, Fisheries Division Special Report 18, Ann Arbor, MI.

Hiltunen, J. K.; Manny, B. A., 1982: Distribution and abundance of macrozooenthos in the Detroit River and Lake St. Clair, 1977. U.S. Fish and Wildlife Service, Great Lakes Fishery Laboratory. Administrative Report 82-2. Ann Arbor, MI.

Holey, M. E.; Baker, E. A.; Thuemler, T. F.; Elliott, R. F., 2000: Research and assessment needs to restore lake sturgeon in the Great Lakes. Results of a workshop sponsored by the Great Lakes Fishery Trust, Lansing, MI.

Homola, J. J.; Scribner, K. T.; Baker, E. A.; Auer, N. A., 2010: Genetic assessment of straying rates of wild and hatchery reared lake sturgeon (Acipenser fulvescens) in Lake Superior tributaries. J. Great Lakes Res. 36, 798-802.

Knights, B. C.; Vallazza, J. M.; Zigler, S. J.; Dewey, M. R., 2002: Habitat and movement of Lake Sturgeon in the upper Mississippi River system, USA. Trans. Am. Fish. Soc. 131, 507-522.

Leach, J. H., 1972: Distribution of chlorophyll $a$ and related variables in Ontario waters of Lake St. Clair. Proc. 15th Conf. Great Lakes Res. 1972, 80-86.

Leach, J. H., 1973: Seasonal distribution, composition, and abundance of zooplankton in Ontario waters of Lake St. Clair. Proc. 16th Conf. Great Lakes Res. 1973, 54-64.

Leach, J. H., 1980: Limnological sampling intensity in Lake St. Clair in relation to distribution of water masses. J. Great Lakes Res. 6, $141-145$.

Lyons, J.; Kempinger, J. J., 1992: Movements of adult lake sturgeon in the Lake Winnebago system. Wisconsin Department of Natural Resources, Research Report 156, Madison, WI.

Manny, B. A.; Kennedy, G. W., 2002: Known lake sturgeon (Acipenser fulvescens) spawning habitat in the channel between lakes Huron and Erie in the Laurentian Great Lakes. J. Appl. Ichthyol. 18, $486-490$.

Manny, B. A.; Morh, L., 2010: Rehabilitation of lake sturgeon in the Great Lakes. Great Lakes Fisheries, Management and Policy. Michigan State University Press, East Lansing, MI.

Meehan, W. E., 1909: Experiments in sturgeon culture. Trans. Am. Fish. Soc. 39, 85-91.

Mosindy, T.; Rusak, J., 1991: An assessment of lake sturgeon populations in Lake of the Woods and the Rainy River, 19871990. Lake of the Woods Fisheries Assessment Unit, Technical Report No.1991-01, Toronto, ON, Canada.

Nichols, S. J.; Kennedy, G.; Crawford, E.; Allen, J.; French, J., III; Black, G.; Blouin, M.; Hickey, J.; Chernyák, S.; Haas, R.; Thomas, M., 2003: Assessment of lake sturgeon (Acipenser fulvescens) spawning efforts in the lower St. Clair River. J. Great Lakes Res. 29, 383-391.

Post, H., 1890: The Sturgeon; some experiments in hatching. Trans. Am. Fish. Soc. 19, 36-40.

Priegel, G. R.; Wirth, T. L., 1971: The lake sturgeon: its life history, ecology and management. Wisconsin Department of Natural Resources, Publication 240, Madison, WI.

Priegel, G. R.; Wirth, T. L., 1978: Lake sturgeon populations, growth, and exploitation in lakes Poygan, Winneconne, and Butts Des Morts, Wisconsin. Wisconsin Department of Natural Resources, Technical Bulletin No. 107, Madison, WI.

Rand, M. C.; Greenberg, A. E.; Taras, M. J.; Franson, M. A. (Eds), 1975: Standard methods for examination of water and wastewater, 14th edn. American Public Health Association, Washington, DC.

Rossiter, A.; Noakes, D. L. G.; Beamish, F. W. H., 1995: Validation of age estimation for the lake sturgeon. Trans. Am. Fish. Soc. 124, $777-781$.

Roussow, G., 1957: Some considerations concerning sturgeon spawning periodicity. J. Fish. Res. Board Can. 14, 553-572.

Rusak, J. A.; Mosindy, T., 1997: Seasonal movements of lake sturgeon in Lake of the Woods and the Rainy River, Ontario. Can. J. Zool., 75, 395. doi: 10.1139/z97-048.

Schwab, D. J.; Clites, A. E., 1986: The effect of wind-induced circulation on retention time in Lake St. Clair. Proceedings of 29th Conference of Great Lakes Research, The International Association for Great Lakes Research, Abstract.

Swets, J. A., 1988: Measuring the accuracy of diagnostic systems. Science 240, 1285-1293.

Thomas, M. V.; Haas, R. C., 1998: Evaluation of lake sturgeon populations in the St. Clair River and Lake St. Clair. federal aid annual performance report, project F-53-R-14, study 491. Michingan Department of Natural Resources, Fisheries Division, Ann Arbor, MI.

Thomas, M. V.; Haas, R. C., 1999: Capture of the Lake Sturgeon with setlines in the St. Clair River, Michigan. N. Am. J. Fish. Manag. 19, 610-612.

Thomas, M. V.; Haas, R. C., 2000: Evaluation of lake sturgeon populations in the St. Clair River and Lake St. Clair. federal aid annual performance report, project F-53-R-14, study 491 Michingan Department of Natural Resources, Fisheries Division, Ann Arbor, MI.

Thornley, S., 1985: Macrozoobenthos of the Detroit and St. Clair rivers with comparisons to neighboring waters. J. Great Lakes Res. 11, 290-296.

Threader, R. W.; Brousseau, C. S., 1986: Biology and management of the lake sturgeon in the Moose River, Ontario. N. Am. J. Fish. Manag. 6, 383-390.

Author's address: James C. Boase, US Fish and Wildlife Service, Alpena Fish and Wildlife Conservation Office Waterford Sub-station, 7806 Gale Road, Waterford, MI 48327, USA.

E-mail: james_boase@fws.gov 